\title{
Discovering the Self in Islam: Self-Striving, Self-Regard, and Self-Neglect
}

\author{
Mustafa Tekke (Corresponding Author) \\ $\mathrm{PhD}$ Candidate, Institute of Education, International Islamic University Malaysia, \\ Jalan Gombak 53100 Kuala Lumpur \\ mustafatekke@gmail.com \\ Nik Ahmad Hisham Ismail \\ Institute of Education, International Islamic University Malaysia, \\ Jalan Gombak 53100 Kuala Lumpur \\ nikahmad@iium.edu.my
}

\begin{abstract}
This study explored some self domains and reviewed them through Islamic perspective, more particularly self-knowledge and faith. It provided an extensive literature on particular concepts of selfstriving, self-regard, and self-neglect. To briefly point out, the self has many origins, however deeply noted as such heart, spirit, and psyche in Islam. From these, this study looked at the two known self domains: self-striving, and self-regard. Apart from these concepts, researchers differently chose selfneglect. With this, the study indicated the self-neglect is an important concept as defensive behavior and these all self concepts might be useful as a central of human nature for future experimental development.
\end{abstract}

Keywords: self, Islam, self-striving, self-regard, self-neglect, personality

\section{Introduction}

The self has many domains in conventional personality theories. It can reveal the origin of transpersonal knowledge (Jung, 1933), a regulatory system for personality interaction (Sullivan, 1953), motivation for psychological development (Maslow, 1954), and the development of positive virtues (Baumeister \& Exline, 1999).
In addition to this, according to Inayat (2005), the self is understood with various concepts such as heart, spirit, and psyche in Islam; heart (qalb) is the most important, refers to individually the deepest spiritual wisdom. It is through the heart that the individual links to God and fulfills Divine unity (Tawhid), the devotion aspect of Islam. "The heart provides a Muslim with a more profound level of understanding of the world than rational intelligence" (Smither \& Khorsandi, 2009, 
p.87). The spirit (roh) is defined as God's breath in the verse of the Qur'an, forming innate nature of human (Haque, 2002), energy of life (Abu-Raiya, 2012), affect one's behavior. Beyond this, it is believed in Islam that a life without spirit is not a way to pursue physically. In this sense, spirit provides the energy for a person's spiritual and physical development (Smither \& Khorsandi, 2009), which operates through the body.

In their development of an Islamic personality of psychology, Haque and Mohamed (2009) grounded their work in the concept of fitrah (nature), which was defined as the "innate and natural disposition of man to believe and worship God" As a further basis for relationship with God, they asserted "the key to knowledge of God is knowledge of one's self both inwardly and outwardly". Earlier, Mohamed (1998) claimed that "fitrah, together with divine revelation, allows humans to attain all levels of perception, even the knowledge of Allah in a direct and immediate way" (p.97).

The Prophet said related the hadith (Tirmidhi, Jihad, 2) on nafs; 'The real mujahid is he who makes jihad (fight) against his nafs for the sake of Allah'; and in the Qur'an (Yusuf: 53), it is stated that 'indeed, the soul (nafs) is a persistent enjoiner of evil'. That understanding and conquest of the self is incumbent upon a Muslim at all the time. It, thus, can be interpreted that the one who is striving to know oneself against his nafs knowing God, meaning that true knowledge of the self would lead one to closeness with the Creator. In a sense, one should be aware of selfknowledge and the ability of striving toward God, that might lead to enhance the strength of one's inner workings or the essence and personal strivings (Quinn, 2008). Considering self theory, we will divide the self into three domains to understand it in depth.

\section{Self-striving}

Self-striving is considered intrinsic and natural in one's being and refers to the typical goals that a person characteristically is trying to accomplish (Emmons, 2005). Striving might be oriented with faith (iman) and virtuous behavior (amal saleh) (Tekke, Ismail, Adnan \& Othman, 2015). It is also understood the importance of faith to lead an individual to self-striving, in other words self-striving is initiated by the faith (Nursi, 1930/2003). Fowler (1981) also pointed out the "faith is an integral part of one's character or personality" (p. 92). In Islam, nafs is essentially enjoiner of evil and desires against faith, as stated in the Qur'an and Hadith above, striving, thus, is an emphasis on the action-oriented against 
desires of nafs. That sort of challenge represents virtuous behavior in Islam.

Some commitments of examples related to the striving by Emmons (2005), are as follows;

"-Work toward higher athletic capabilities

-Meet new people through my present friends

-Accept others as they are

-Not be a materialistic person

-Always be thankful, no matter what the circumstances

-Reciprocate kindnesses

-Do what is pleasing to God "(p.733)

Consistently above, the teachings of Prophet Muhammad are in line with similar commitments to promote the values in individual and society all together, referring also to another type of virtuous behavior in Islam.

Given that self-striving is associated with collective self (Ellemers, Spears, \& Doosie, 2002) which strives for the community. It is concerned the characteristics of one's groups, which may or may not also characterize oneself as an individual (Crocker \& Luhtanen, 1990). While Tahir and Sohail (2012) explain the ethical life in Islam, they believe selfbuilding is initiative toward society building; in other words, a personal good becomes a collective good.

\section{Self-regard}

Self-regard is described as the ability of self worth and strength (Somers, 1989), and initiated by actualizing tendency (Rogers, 1954). Rogers believed that all people have a need for positive self-regard. To Rogers, positive self-regard is the pathway to psychological health. In the absence of such self-regard, the individual's need for a positive self-view may be unfulfilled, leading to psychological distress (Cervone \& Pervin, 2008).

Rogers (1954) integrated the positive selfregard with organismic valuing, and needs. This allow to develop the sense of real-self. Rogers believed that we all own a real self. The real self is related to self regard. It's the self that feels most true to what and who we really are.

Positive regard. It is a fact universally that there is a need for positive regard which develops as the self concepts appears and which the individual attempts to be satisfied. The individual learns to correlate positive regards from others with certain selfexperiences while the self-concept develops. 
With this manner the individual finds out to experience self-regards independent of experiences with others (Rogers, 1959).

\section{Unconditional positive regard. In Rogers's} view, the ideal condition for development of a healthy self-concept and movement toward becoming fully functioning person is unconditional positive regards, uncorrupted by evaluations or judgments of our thoughts, feelings, or behaviors, a deep and genuine caring by others (Rogers \& Sanford, 1984). The unconditional positive regard therefore helps the person feel free to act and try out, even though this may sometimes lead to get the hardship. For an individual, this moreover helps to self actualize at the end. Islam supports the importance of positive regard such as morality, and indeed one of the responsibility of Prophets of God was to establish high morality in society (Nik Mustapha, 1994).

\section{Self-neglect}

Self-neglect is not described directly by psychologists, but it is associated with the meaning of materialism defined in with the Oxford English Dictionary "devotion to material needs or desires, to the neglect of spiritual matters; a way of life, opinion, or tendency based entirely upon material interests." Traditionally, self-neglect, as a concept and a condition, has been contrasted to spirituality and vice versa (Case, 1997) and also associated with committing sin (Andreason, 1972).

However, very recently, Ryum and his colleagues (2015) has discussed that improving positive feelings about the self is emphasized as central for change in dynamic psychotherapy, achieved by challenging defensive behaviors such as self-attack and self-neglect. Self-neglect is interpreted in the field of counseling as merely product of defensive reaction (Şimşek, 2005). On the other hand, Krauss, Hamzah, Juhari, and Hamid (2005) argued that virtuous behavior creates some effect on the self; if positive feeling of behavior is emphasized, it strengthens the quality of self so that good acts/behaviors are established in the self. Selfneglect, therefore, might not be misleading toward spirituality and Islamic personality; it might occur as a defensive reaction in particular circumstances and perhaps motivation for mysticism (James, 1902/1985).

Furthermore, the purpose of human life in Islam is essentially to do worship (Ibadah) or commitment to God, as stated in the Qur'an, and one's duty is obedience to God. But human being is literally in Arabic, also 
"composed of forgetfulness (nisyan)," and innately created to forget to fulfill his or her duty and purpose to the God ( concern sin in Islam) as indicated below in the Qur'an (Taha:115):

"Indeed, man is called
insane because, having
covenanted with Him, he
forgot".

Forgetfulness is, though natural phenomena, viewed as the cause of man's disobedience in the context of Ibadah, and this blameworthy nature inclines him towards injustice and ignorance, implied in the Qur'an (Ahzab:72). But God has equipped human with the faculties (i.e., intelligence) of right vision and apprehension, of real savoring of truth and right speech and communication; and has indicated to human the right and the wrong through holy books and Prophets- with respect to the course of action he or she should take so that a person might strive to attain his or her bright destiny. Even though his or her intelligence might confuse him or her, and provided he is sincere and true to God, that motivate him or her attain to truth and right conduct ( al-Attas, 1993).

\section{Conclusion}

This extensive review of literature regarding self in Islam expounds relevant self dimensions referring to well-known concepts of self. Additionally, this review essentially provides the understanding or perspective of self in Islam to the relevant researchers. Self is studied by some researchers but as for dimensions, it is still inadequate in Islamic literature. However, this gains an importance to study on particularly personality over Muslim.

Firstly, self-striving representing faith and virtues behavior is considered as central to figure out a Muslim's striving toward religion. Secondly, self-regard is mainly known from Carl Rogers' self theory to represent positive regard for a person's self development. However, in this review, extending the self to society, morality resulting from self-regard is inevitably important for every religion including Islam and culture. As for third self related domain, self-neglect is unlikely studied and reviewed by the researchers. Its importance related to self comes from the broad meaning nafs, to some extent, nafs is viewed as enjoiner of evil and hatred feelings of human in Islam, mainly based on Qur'an and Hadith.

As a result, this study highlights the descriptions of self domains integrated with Islam. The concept of self in Islam is limited to only self-striving, self-regard, and selfneglect. It would be beneficial to consider 
some other relevant self domains to help to understand the self in Islam in a broad. Finally, this study might be in an initial position to develop related experimental scales.

\section{References}

Abu-Raiya, H. (2012). Towards a systematic Qura'nic theory of personality. Mental Health, Religion \& Culture, 15(February 2015), 217-233. doi:10.1080/13674676.2011.640622.

Abu-Raiya, H. (2015). Working with religious Muslim clients: A dynamic, Qura'nic-based model of psychotherapy. Spirituality in Clinical Practice, 2(2), 120-133. doi:10.1037/scp0000068.

Al-Attas, S.M.N. (1993). Islam and secularism. Kuala Lumpur: International Institute of Islamic Thought and Civilization.

Andreason, N. J. C (1972). The role of religion in depression. Journal of Religion and Health, 11, 153-166.

Baumeister, R. F. \& Exline, J. (1999). Virtue, Personality, and Social Relations: Self-Control as the Moral Muscle. Journal of Personality, 67, 1165-1194. doi: 10.1111/1467-6494.00086.

Berke, J. H., \& Schneider, S. (2006). The self and the soul. Mental Health, Religion \& Culture, 9(4), 333-354. doi:10.1080/13694670500116888.

Case, B. T. (1997). Further validation of the forgiveness of self (FOS) and forgiveness of others (FOO) scales and development of the potential barriers to forgiveness scale. Retrieved from Purdue University. (UMI 9818930).

Cervone, D., \& Pervin, L. A. (2008). Personality: Theory and research (10th ed.). Hoboken, NJ: John Wiley \& Sons.

Crocker, J., \& Luhtanen, R. (1990). Collective self-esteem and in group bias. Journal of Personality and Social Psychology, 58(1), 60-67. doi:10.1037//0022-3514.58.1.60

Dixon, R. (2007). Systemic thinking: A framework for research into complex psychosocial problems. Qualitative Research in Psychology, 4(1-2), 145-166. doi:10.1080/14780880701473532

Ellemers, N., Spears, R., \& Doosie, B. (2002). Self and social identity. Annual Review of Psychology, 53, 161-196. 
Emmons, R. A. (2005). Striving for the sacred: Personal goals, life meaning, and religion. Journal of Social Issues, 61(4), 731-745. doi:10.1111/j.1540-4560.2005.00429.x

Eysenck, H.J. \& Eysenck, S.B.G. (1976). Psychoticism as a dimension of personality. London: Hodder and Stoughton

Fowler, J.W. (1981). Stages of faith: The psychology of human development and the quest for meaning. San Francisco: Harper \& Row.

Haque, A. (2002). Psychology of Religion: Analysing Religious Development, Orientation and Negative Social Behaviors. Indian Social Science Review, 4(1), 25-43.

Haque, A., \& Masuan, K. A. (2002). Religious psychology in Malaysia. International Journal for the Psychology of Religion, 12(4), 277-289. doi:10.1207/S15327582IJPR1204_05

Haque, A., \& Mohamed, Y. (Eds.). (2009). Psychology of personality: Islamic perspectives. Kuala Lumpur, Malaysia: Cengage.

Inayat, Q. (2005). The Islamic concept of the self. British Counselling Review, 20, 2-10.

James, W. (1985). The varieties of religious experience. Cambridge, MA: Harvard University Press (Originally work published 1902)

Jung, C. G. (1933). Modern man in search of a soul. New York: Harcourt, Brace \& World.

Krauss, S.E., Hamzah, A.J., Juhari, R., \& Hamid, J.A. (2005). The Muslim Religiosity-Personality Inventory (MRPI): Towards understanding differences in the Islamic Religiosity among the Malaysian youth. Journal of Social Sciences and Humanities, 13(2), 173-186.

Maslow, A. H. (1954). Motivation and personality. New York: Harper \& Row.

Mohamed, Y. (1998). Human nature in Islam. Kuala Lumpur: Nordeen.

Nik Mustapha, N.H. (1994). The relevance of human centred development in the industrial era. IKIM Journal, 2(1),79-92.

Nursi, S. (2003). Sozler (The Words). Istanbul: Sozler (Originally work published 1930)

Rogers, Carl R. (1954). Psychotherapy and personality change. Chicago: University of Chicago Press 
Rogers, C. R., \& Sanford, R. C. (1984). Client-centered psychotherapy. In H. I. Kaplan\& B. J. Sadock (Eds.), Comprehensive textbook of psychiatry (Vol. 4, pp. 1374-1388). Baltimore: Williams \& Wilkins.

Ryum, T., Vogel, P. a, Walderhaug, E. P., \& Stiles, T. C. (2015). The role of self-image as a predictor of psychotherapy outcome. Scandinavian Journal of Psychology. 56(1),62-68. doi:10.1111/sjop.12167

Şimşek, Ö. F. (2005). Paths from fear of death to subjective well-being: A study of structural equation modeling based on the terror management theory perspective. Retrieved from Albert Ellis Institute. Middle East Technical University, Ankara

Somers, M. (1989). Adjustment to retirement as a function of self-actualization and personality type. Retrieved from Proquest. (8917316).

Smither, R., \& Khorsandi, A. (2009). The implicit personality theory of Islam. Psychology of Religion and Spirituality, 1(2), 81-96. doi:10.1037/a0015737

Sullivan, H. S. (1953). The interpersonal theory of psychiatry. New York: Norton.

Tahir, A. R., \& Sohail, M. (2012). The concept of ethical life in Islam. Interdisciplinary Journal of Contemporary Research In Business, 3(9), 1360-1369. Retrieved from from:http://search.proquest.com/docview/964018844? accountid=28930.

Tekke, M., Ismail, N. A. H., Adnan, M. A. M., \& Othman, N. (2015). Students `Islamic personality on amanah : A structural modelling approach. Social Sciences \& Humanities, 23(1), 1-10.

Quinn, P. (2008). God and humans in Islamic thought. 'Abd al-Jabbar, Ibn Sina and al-Ghazali. Philosophy East \& West, 58(2), 293-296. doi:10.1353/pew.2008.0020

Yocum, R. (2014). Spiritual development and education: A sequential mixed-methods approach. Religion \& Education, 41(1), 80-99. doi:10.1080/15507394.2012.716351 